\title{
Human Adenovirus and Human Cytomegalovirus Infections in Preterm Newborns: No Association with Bronchopulmonary Dysplasia
}

\author{
SUSANNA PRÖSCH, UTA LIENICKE, CHRISTINA PRIEMER, GISELA FLUNKER, \\ WERNER F. SEIDEL, DETLEV H. KRÜGER, AND ROLAND R. WAUER \\ Departments of Virology [S.P., C.P., D.H.K) and Neonatology [U.L., R.R.W.], Humboldt University, \\ Medical School (Charité), D-10098 Berlin, Germany, Friedrich-Loeffler-Institute of Medical Microbiology \\ [G.F., W.F.S.], Ernst-Moritz-Arndt University, D-17489 Greifswald, Germany
}

\begin{abstract}
Connatal infection with human adenovirus (HAdV) has been recently proposed as a cofactor for the development of bronchopulmonary dysplasia (BPD) in preterm infants [Couroucli et al. 2000 Pediatr Res 47:225-232]. In another study, BPD was associated with an increased incidence of human cytomegalovirus (HCMV) infection [Sawyer et al. 1987 Am J Dis Child 141:303-305]. During a 18-mo study period, we investigated tracheal aspirates or pharyngeal aspirates and urine samples collected during the first month of life from 66 preterm newborns with very low birth weight $(\leq 1.500 \mathrm{~g})$ for replication-potent HAdV as well as for adenoviral and HCMV DNA by virus culture and qualitative DNA PCR. Thus, our study included not only prenatal but also peri- and postnatal infections. Thirty-seven percent $(24 / 66)$ of infants developed $\mathrm{BPD}_{1}$, as defined by persistent oxygen dependency at day 28 of life. Replication-potent HAdV and/or adenoviral DNA could be detected repeatedly in tracheal aspirates/pharyngeal aspirates and/or urine from $20 \%$ $(13 / 66)$ of preterm infants. Seventeen percent (4/24) of infants in the $\mathrm{BPD}_{1}$ group and $21 \%(9 / 42)$ of infants in the non-BPD group had an HAdV infection, indicating that in our study the very recently proposed association between $\mathrm{HAdV}$ infection of the lung and BPD could not be confirmed. For comparison, active HCMV infection was diagnosed in 18\% (12/66) of infants, 3 of
\end{abstract}

which developed HCMV disease. $29 \%(7 / 24)$ in the $\mathrm{BPD}_{1}$ group and $12 \%(5 / 42)$ in the non-BPD group were positive for HCMV. Again, there was no statistically significant association between HCMV infection and BPD. In summary, our findings indicate that HAdV and HCMV infection are frequent in preterm newborns with very low birth weight; however, a causal association with the development of BPD seems unlikely. (Pediatr Res 52: 219-224, 2002)

Abbreviations
AI, Amniotic infection
Bp, Base pair
Kbp, Kilo base pairs
BPD, Bronchopulmonary dysplasia
BPD, BPD diagnosed at day 28 post gestation
BPD, BPD diagnosed at 36th postconceptional weeks
HAdV, Human adenovirus
HCMV, Human cytomegalovirus
IE, Immediate early
DNTPs, Dideoxynucleotide triphosphates
PA, Pharyngeal aspirates
RDS, Respiratory distress syndrome
TA, Tracheal aspirates

According to the epidemiologic data of the Vermont-Oxford database from 1997, 40 to $50 \%$ of preterm newborns delivered before 32 wk of gestation with a birth weight $\leq 1.500 \mathrm{~g}$ developed BPD, a chronic lung disease, defined by persistent oxygen dependency at day 28 of life $\left(\mathrm{BPD}_{1}\right)$, or, alternatively, at 36 postconceptional weeks $\left(\mathrm{BPD}_{2}\right)(1)$. Today, $\mathrm{BPD}$ is best

Received December 12, 2001; accepted February 26, 2002.

Correspondence and reprint requests: Susanna Prösch, $\mathrm{PhD}$, Institute of Virology, Humboldt University Medical School (Charité), D-10098 Berlin, Germany; e-mail: susanna.proesch@charite.de

This work was supported by Grant 01ZZ9511 from the German Ministry of Research and Technology and Deutsche Forschungsgemeinschaft SFB 421.

DOI: $10.1023 / 01 . P D R .0000020087 .83266 .71$ understood as an injury and repair process occurring in the immature lung secondary to pulmonary oxygen toxicity, respirator-induced volutrauma, inflammation, and connatal infection by pathogens such as Ureaplasma urealyticum, Chlamydia tracheomatis, Mycoplasma hominis, or human cytomegalovirus $(2-7)$.

Very recently, Couroucli and his colleagues (8) observed a significantly increased frequency of HAdV in TA from infants with BPD (defined as oxygen dependency at day 28 of life) when compared with those without BPD. In the same study, no association was found between development of BPD and detection of HCMV, enteroviruses, parvovirus B19, Mycoplasma pneumoniae, U. urealyticum, C. tracheomatis or M. hominis. 
HAdV and HCMV can cause persistent infections in humans. Both viruses can be transmitted prenatally and vaginally from mother to infants (9-13). Mothers often have viral symptoms preceding or shortly after delivery and there may be prolonged rupture of membranes (11). Furthermore, for HCMV, postnatal transmission by breast-milk in about 37 to $60 \%$ of seropositive mothers and their preterm infants has been documented (14-17). The clinical outcome of both HAdV as well as HCMV infection in preterm newborns is variable, ranging from asymptomatic infection to fatal life-threatening diseases, such as sepsis-like disease $(10,11,13,17)$.

The aim of the present article was to determine (1) the incidence of upper airway infection by HAdV and HCMV in preterm infants born $\leq 32 \mathrm{wk}$ of gestation and (2) its coincidence with BPD at day 28 of life $\left(\mathrm{BPD}_{1}\right)$ and at 36 postconceptional weeks $\left(\mathrm{BPD}_{2}\right)$. Therefore, a prospective clinical study was initiated to screen weekly TA or PA and urine of preterm newborns during the first month of life for replicationpotent HAdV as well as adenoviral and HCMV DNA.

\section{METHODS}

Patients and study design. The infants of this study population were recruited as part of a prospective study between May 1999 and October 2000. Sixty-six infants from 55 mothers were enrolled into the study after parental consent was obtained. The study has been approved by the Ethics committee of the Medical School Charité. Infants with serious malformations and undetermined metabolic disorders were excluded, as were infants who died within the first 2 weeks of life. BPD was defined as oxygen dependency at day 28 of life $\left(\mathrm{BPD}_{1}\right)$ or at the time of 36 postconceptional weeks $\left(\mathrm{BPD}_{2}\right)$ (1). Of the study population, $36.6 \%(24 / 66)$ developed $\mathrm{BPD}_{1}$; half of them $(12 / 66)$ even developed $\mathrm{BPD}_{2}$. The clinical data for the BPD and the non-BPD groups are shown in Table 1. All blood products given to the infants are routinely and stringently screened for HCMV IgG antibodies. Only CMV-negative blood products were given.

Specimens. Tracheal aspirates were collected at days 1, 3, 5, 7,14 , and 28 of life after installation of $0.5 \mathrm{~mL}$ of sterile saline into the endotracheal tube by gentle aspiration through the endotracheal tube into a sterile tube as long as the babies were ventilated. In spontaneously breathing infants, PA were collected. Urine was sampled on the same days. All specimens were immediately frozen and stored at $-20^{\circ} \mathrm{C}$ until DNA preparation.

Nucleic acid preparation and PCR. For PCR, DNA from $200 \mu \mathrm{L}$ TA/PA or urine was prepared using the QIAamp blood

Table 1. Characterization of the study group $(n=66)$

\begin{tabular}{lccc}
\hline & $\begin{array}{c}\text { No BPD } \\
(n=42)\end{array}$ & $\begin{array}{c}\mathrm{BPD}_{1} \\
(n=24)\end{array}$ & $\begin{array}{c}\mathrm{BPD}_{2} \\
(n=12)\end{array}$ \\
\hline Gestational age (weeks) & 29 & 26 & 26 \\
& $(24-32)$ & $(24-29)$ & $(24-29)$ \\
Birth weight (g) & 1170 & 828 & 815 \\
Days of ventilation & $(530-1.500)$ & $(380-1.190)$ & $(380-1.190)$ \\
& 2 & 25 & 34 \\
& $(0-18)$ & $(7-83)$ & $(16-83)$ \\
\hline
\end{tabular}

Kit (QIAGEN GmbH, Hilden, Germany) following the manufacturer's protocol. The primers for HAdV DNA amplification correspond to hexon gene sequence. Single step amplification generating a $281 \mathrm{bp}$ DNA fragment occurred as described by Poddar (18). The lowest threshold of HAdV PCR is 3 to 10 genomes per reaction. For sequence analysis, a hexon-specific $1,807 \mathrm{bp}$ fragment was generated by nested PCR (19).

Amplification of HCMV-specific DNA generated a $123 \mathrm{bp}$ fragment complementary to the IE 1 region and was done as described earlier (20). The lowest threshold of HCMV-DNA PCR is 10 to 50 viral DNA genomes per reaction $(20,21)$; PCR does not detect latent HCMV infection. TA/PA negative for HCMV or HAdV DNA were probed for successful DNA preparation by beta globin PCR according to Bauer et al. (22).

PCR products were separated on a $3 \%$ agarose gel stained with ethidium bromide: specificity of all amplification products was proven by fragment length comparison with standards and hybridization with an internal oligonucleotide as well as sequence analysis (see below). To exclude false positive results by contamination as much as possible, at least two (usually 3 to 10) consecutive samples from each infant were investigated independently for HAdV and HCMV. Furthermore, individual samples from one infant were prepared and amplified independently at different days with negative and positive controls, each.

Sequence analysis. Amplified HAdV DNA was sequenced by using PRISM ready reaction cycle sequencing protocol on an ABI 310 automated DNA-sequencer (Applied Biosystems, Foster City, CA, USA ). A total of 4 primers were used to sequence partially the 7 hypervariable regions of the hexon fragment of 1,807 bp (19). 21 hexon gene sequences of different HAdV of all subgenera were derived from GenBank. The clinical serotype of specimens was determined by multiple sequence alignment using CLUSTAL X (23).

Southern blot analysis. To test for specificity amplified DNA-fragments, HAdV as well as HCMV were transferred to nylon membranes (Schleicher and Schuell, Germany) and hybridized with an internal ${ }^{32} \mathrm{P}-\gamma$ ATP (Hartman Analytic, Germany) end-labeled oligonucleotide, specific either for HCMV or HAdV $(18,20)$. Hybridization was carried out as described earlier (20).

Virus culture. For HAdV isolation, TA or PA was inoculated on Hep2 (clone 2B; ECACC No 85011412) monolayer and daily controlled over 3 wk until cytopathogenic effects became visible. At this time point, aliquots of $200 \mu \mathrm{L}$ culture medium were tested for HAdV DNA by PCR as described.

Procedure. For HAdV DNA, two independently collected TA/PA samples (day 5 and day 7) of all infants were investigated by independent PCR techniques, one single step PCR and two independent nested PCRs, in two different laboratories. If at least one TA or PA was positive for HAdV DNA, additional specimens (TA/PA and urine) taken at day 1, 3, 14, and 28 were investigated by PCR. For all infants, HAdV PCR was confirmed in a second laboratory using different PCR protocols. Aliquots of positive as well as some negative control TA/PA samples were inoculated on cell culture for virus isolation. HCMV-DNA PCR was routinely done at days 1, 3, $5,7,14$, and 28 from TA/PA and urine. For four infants, 
HCMV PCR was confirmed independently in a second laboratory using different primers (data not shown). Active HAdV and HCMV infection was defined by repeated amplification of viral DNA from at least three consecutive samples.

Statistical analysis. Statistical significance was evaluated by the nonparametric Mann-Whitney or the Kruskal-Wallis test using the software Statgraphics 7.0 (Manogistics, USA). The significance level was set at $p<0.05$.

\section{RESULTS}

To answer the question about association between HAdV or HCMV infection and BPD, we screened TA/PA and urine of 66 preterm infants for viral DNA as well as replication-potent virus (HAdV) during the first month of life. As a result, TA/PA and/or urine from 13 of 66 infants were repeatedly and reproducibly positive for HAdV DNA using single step PCR and HAdV isolation on cell culture (with one exception), indicating an overall incidence of $20 \%$ (Table 2). By the amplification of beta globin-specific DNA from all TA and PA samples that were negative for viral DNA, the successful preparation of DNA could be verified. In all infants, HAdV-specific DNA could be detected as early as the first week of life, persisting for at least 2 (patients 1,3 and 4 in Table 3), and mostly for 3 to 4 , wk. For seven infants, the type of HAdV could be determined as HAdV type 2 by sequence analysis; one infant was doubly infected with HAdV type 2 and HAdV type 3 (Table 3 ). The sequence variability of analyzed hexon gene regions with approximately one nucleotide change per 100 nucleotides is very low (not shown). No correlation existed to the mode of birth or days on the ventilator between infected and uninfected infants [2 (0-29) days versus $7(0-83)$ days]. Interestingly, of the 13 infants infected with HAdV, $9(69 \%)$ had an AI and 5 (38\%) developed RDS. In infants without HAdV infection, AI and RDS were observed in 8 of $42(19 \%)$ and in 3 of $42(7 \%)$, respectively.

For comparison, the rate of active HCMV infections in the study group was $18 \%(12 / 66)$ (Table 2). Two of the 12 newborns were born with signs of prenatal HCMV infection, 6 children became HCMV-positive during the first week, while 4 infants were postnatally infected. In the latter group, HCMVspecific DNA fragments could not be amplified from samples collected before the second or third week of life. From all infants, with one exception, HCMV DNA was amplified from both the upper respiratory tract (TA and PA) and urine (Table 4), indicating systemic infection. One of the infants with postnatally acquired HCMV infection developed an HCMVassociated sepsis-like disease. Similarly to the HAdV-infected

Table 2. HAdV and HCMV DNA detection in TA or PA and urine samples from preterm infants with $B P D$ or without $B P D$ during the first month of life $(n=66)$

\begin{tabular}{lcccc}
\hline Virus & $\begin{array}{c}\text { Incidence } \\
(\%)\end{array}$ & $\begin{array}{c}\mathrm{BPD}_{1} \\
(\%)\end{array}$ & $\begin{array}{c}\text { No BPD } \\
(\%)\end{array}$ & $\begin{array}{c}p \mathrm{BPD}_{1} v s \text { no } \\
\mathrm{BPD}\end{array}$ \\
\hline HAdV & $13 / 66$ & $4 / 24$ & $9 / 42$ & \\
& $(20)$ & $(17)$ & $(21)$ & NS \\
HCMV & $12 / 66$ & $7 / 24$ & $5 / 42$ & \\
& $(18)$ & $(29)$ & $(12)$ & NS \\
\hline
\end{tabular}

NS, not significant. infants, the $12 \mathrm{HCMV}$-infected newborns showed a high rate of $\mathrm{AI}(8 / 12,67 \%)$ or of $\operatorname{RDS}(8 / 12,67 \%)$. Two infants were infected by both HAdV and HCMV. Notably, infants with HCMV infection were significantly longer on the ventilator than those without HCMV infection [15 (0-83) days versus 5.5 (0-46) days].

In our study, 24 of $66(36.6 \%)$ infants developed $\mathrm{BPD}_{1}$, but only 4 of them (17\%) were found to be positive for HAdV in TA/PA (Table 2). Similarly, in the non- $\mathrm{BPD}_{1}$ group, 9 of 42 infants $(21 \%)$ were infected by HAdV. HCMV infection was diagnosed in 7 of $24(29 \%)$ infants with $\mathrm{BPD}_{1}$ and in only 5 of $42(12 \%)$ in non-BPD infants. The differences, however, were not statistically significant. $\mathrm{BPD}_{1}$ was developed by both prenatally infected infants, $2 / 6(33 \%)$ of infants already positive for HCMV during the first week of life, and $3 / 4(75 \%)$ of postnatally infected infants (Table 4). Of the two infants with double infection (HAdV and HCMV), one had $\mathrm{BPD}_{1}$, the other did not.

\section{DISCUSSION}

Bronchopulmonary dysplasia is a common severe complication in preterm newborns. Infection by various pathogens such as bacteria and viruses are thought to be a coincidental risk factor for the development of this disease; however, the data are controversial with respect to the involvement of viral infection. While Sawyer et al. (6) reported an association between HCMV infection and BPD, Couroucli et al. (8) observed a significant association between HAdV infection but not HCMV infection and the development of BPD. From these data, the authors concluded that HAdV and not HCMV infection might be a risk factor for the development of this severe lung disease.

In this similarly designed study, we screened 66 preterm infants for HAdV and HCMV infection after birth over a period of $4 \mathrm{wk}$. However, no association between development of $\mathrm{BPD}_{1}$ and the occurrence of a HAdV infection could be observed. In our study group, $17 \%$ (4/24) of infants with $\mathrm{BPD}_{1}$ and $21 \%(9 / 42)$ of infants without BPD repeatedly tested positive for adenoviral DNA in TA/PA and urine. This relationship did not change if we used the alternative BPD definition: persistent oxygen dependency at an age of 36 postconceptional weeks $\left(\mathrm{BPD}_{2}\right)$. In 12 infants fulfilling this $\mathrm{BPD}$ definition $\left(\mathrm{BPD}_{2}\right)$, only one child was infected by HAdV $(8 \%)$. In the non- $\mathrm{BPD}_{2}$ group, $12 / 54(22 \%)$ infants were positive for HAdV.

In all 13 infants tested positive for HAdV DNA, the infection was confirmed by virus isolation on cell culture inoculated with TA/PA collected at day 5 and/or 7 of life. Remarkably, in all infants, the virus was detectable in TA/PA during the first week of life and persisted for at least 2, mostly for 3 to 4 , wk. Thus, our study, despite including a closely related group of patients, did not confirm the observed association between BPD and HAdV infection described by Couroucli et al. (8).

In contrast to Couroucli et al. (8), HCMV infections were detected in $18 \%(12 / 66)$ of our infants by repeated HCMV DNA amplification from TA/PA and/or urine during the first month of life. Interestingly, there was an apparently increased 
Table 3. HAdV PCR, culture, and typing in TA or PA of $13 B P D_{1}$ and non-BPD infants with HAdV infection

\begin{tabular}{|c|c|c|c|c|c|c|}
\hline $\begin{array}{l}\text { No. of } \\
\text { patient }\end{array}$ & Birth & $\begin{array}{c}\text { PCR } \\
\text { TA/PA }\end{array}$ & $\begin{array}{l}\text { Culture } \\
\text { TA/PA }\end{array}$ & $\begin{array}{c}\text { PCR from } \\
\text { culture }\end{array}$ & $\begin{array}{c}\mathrm{HadV} \\
\text { type }\end{array}$ & $\mathrm{BPD}_{1}$ \\
\hline 1 & Vaginal & + & + & + & HAdV-2 & $\varnothing$ \\
\hline 2 & Vaginal & + & + & + & nd & $\widetilde{\varnothing}$ \\
\hline 4 & Sectio caesarea & + & + & + & nd & $\varnothing$ \\
\hline 5 & Sectio caesarea & + & + & $\varnothing$ & nd & $\varnothing$ \\
\hline 6 & Vaginal & + & + & nd & HAdV-2 & $\varnothing$ \\
\hline 8 & Vaginal & + & + & + & HAdV-2 & + \\
\hline 9 & Sectio caesarea & + & + & nd & nd & + \\
\hline 10 & Sectio caesarea & + & + & nd & HAdV-2 & $\varnothing$ \\
\hline 11 & Vaginal & + & + & + & HAdV-2 & $\varnothing$ \\
\hline 12 & Sectio caesarea & + & + & nd & HAdV-2 & $\varnothing$ \\
\hline 13 & Vaginal & + & nd & nd & nd & $\varnothing$ \\
\hline
\end{tabular}

nd, not done.

Table 4. Infants with $H C M V$ infection: transmission, days of ventilation, $P C R$, and $B P D_{I}$

\begin{tabular}{|c|c|c|c|c|c|c|}
\hline $\begin{array}{l}\text { No. of } \\
\text { patient }\end{array}$ & $\begin{array}{c}\text { HCMV } \\
\text { transmission }\end{array}$ & $\begin{array}{c}\text { Days of } \\
\text { ventilation }\end{array}$ & $\begin{array}{l}\text { PCR } \\
\text { (TA) }\end{array}$ & $\begin{array}{l}\text { PCR } \\
\text { (PA) }\end{array}$ & $\begin{array}{c}\text { PCR } \\
\text { (urine) }\end{array}$ & $\mathrm{BPD}_{1}$ \\
\hline 1 & Prenatal & 39 & + & + & + & + \\
\hline 2 & Prenatal & 23 & + & + & + & + \\
\hline 3 & Unclear & 7 & + & + & + & + \\
\hline 4 & Unclear & 23 & + & + & $\varnothing$ & + \\
\hline 5 & Unclear & 1 & na & + & + & $\varnothing$ \\
\hline 6 & Unclear & 0 & na & + & + & $\varnothing$ \\
\hline 7 & Unclear & 4 & na & + & + & $\varnothing$ \\
\hline 8 & Unclear & 3 & na & + & + & $\varnothing$ \\
\hline 9 & Postnatal & 0 & na & + & + & $\varnothing$ \\
\hline 10 & Postnatal & 83 & + & na & + & + \\
\hline 11 & Postnatal & 38 & + & na & + & + \\
\hline 12 & Postnatal & 33 & + & na & + & + \\
\hline
\end{tabular}

Unclear, infants positive for HCMV infection as early as during the first week of life; na, not available.

incidence of $\mathrm{HCMV}$ infection in infants with $\mathrm{BPD}_{1}$ or $\mathrm{BPD}_{2}$ compared with those without $\mathrm{BPD}\left(29 \%\right.$ versus $12 \%$ for $\mathrm{BPD}_{1}$ versus non $\mathrm{BPD} ; 25 \%$ versus $16 \%$ for $\mathrm{BPD}_{2}$ versus non $\mathrm{BPD}$ ), confirming earlier data of Sawyer et al. (6)). However, the differences between the BPD and the non-BPD groups were not statistically significant. Notably, infants with HCMV infection, especially those with prenatal and postnatal infection, were significantly longer on ventilation than those without infection. The incidence of BPD in pre- and postnatally infected infants is higher compared with those infants for which the time of infection remained unclear. It therefore could be speculated that pre- and postnatal infections increase the risk for BPD in preterm infants; however, the number of HCMVinfected infants in each group is too small to allow clear conclusions.

As demonstrated here, the total incidence of both viruses in preterm infants was $20 \%$ for HAdV and $18 \%$ for HCMV. Among them, two infants (3\%) were coinfected with HAdV and HCMV. In comparison, Couroucli et al. (8) reported a total incidence of $17 \%$ for $\mathrm{HadV}$ - which corresponds very well to our observations - but only 3\% for HCMV. However, comparable with our results, Sawyer et al. (6) as well as Vochem et al. (16) observed HCMV infection in $33 \%$ and $25 \%$ of preterm infants, respectively. Using the more insensitive method of
HCMV isolation in cell culture, Yeager et al. (14) found a HCMV incidence of $17 \%$. Hamprecht et al. (17) observed postnatal HCMV infections in 37\% (33/90) of preterm infants from seropositive, breastfeeding mothers. In all these studies, the overall rate of HCMV infection in preterm infants was much higher than described by Couroucli et al. (8). This discrepancy could be explained by the fact that Couroucli et al. (8) exclusively searched for prenatal HCMV infection, as they studied only TA collected during the first week of life; consequently, postnatally and probably also perinatally transmitted HCMV infections were missed. In our study, prenatal infection could be confirmed in two infants (twins); four infants were infected postnatally (HCMV DNA detection not until the second or third week of life) while from the remaining six infants, HCMV DNA could first be amplified during the first week of life. For these latter children, the time of infection remains unclear, as only two of them were born spontaneously, which would be compatible with vaginal transmission. Therefore, asymptomatic prenatal infections could not be excluded in some of our infants. Symptomatic connatal infections by HCMV usually occur in only $1 \%$ to $4 \%$ of newborns; however, the rate of asymptomatic connatal HCMV infections may be higher $(9,10)$. HCMV DNA could be amplified repeatedly from breast-milk of all mothers (with one exception) of HCMV 
infected infants (not shown), suggesting that these mothers were latently infected with HCMV and that the virus became reactivated during pregnancy or after delivery. Furthermore, all infants with HCMV infection were breast fed. Thus, postnatal infection observed in four infants may be transmitted by maternal breast-milk. However, in the six infants for which the mode of infection remained unclear, TA/PA and/or urine became positive for HCMV DNA before or in parallel with starting breast feeding, suggesting that transmission occurred independently from breast milk.

As mentioned above, HAdV infection was detectable in all infants as early as the first week of life, indicating prenatal or perinatal infection. Remarkably, from the 13 infants with an HAdV infection, 8 (62\%) were born spontaneously, compared with only $2 / 7(29 \%)$ in the group of perinatally HCMVinfected infants. Interestingly, nearly all infants with HAdV infection were born between August and October as well as March and June when respiratory infections by HAdV are most common. Therefore, hospital infection by mothers or staff members cannot completely be excluded. In sera from 7 of 8 mothers of HAdV-infected infants, we detected speciesspecific antibodies against pIX of HAdV-2 and genus-specific antibodies against hexon protein but no or only very low levels of antibodies recognizing the genus-specific receptor-binding fiber protein (not shown). This is a further indication for the importance of the immune response against fiber protein (Bauer et al., unpublished). Therefore, the HAdV immune status of the mothers explains the detection of HAdV infections in infants as well as the fact we found inapparent and no severe infections. An alternative source of infection might be reactivation of a persistent HAdV in mothers followed by subsequent transmission to the infant. From extensive sequencing of isolates from mother as well as infant, we expected to receive further information on the epidemiology of newborn infection by adenovirus. In seven infants, the virus could be identified as HAdV-2, which is known to be frequently associated with respiratory infection (for review see reference 24). One infant was infected both with HAdV-2 and HAdV-3. A comparison of short hexon gene regions of 300 bases among each other allowed us to detect two mutated nucleotides in only of five HAdV isolates obtained from different infants (data not shown). A reactivation of persistent HAdV in the mothers with subsequent connatal infection in infants should have shown more mutations as an epidemic infection. Sequence analysis of HAdV isolates from the cities of Berlin, Greifswald, and Tübingen in the same hexon gene region showed 5-fold more mutations (not shown). Thus, our results support the assumption that HAdV infections observed in infants may result from transmission by hospital infection by means of staff personnel or mothers reinfected with a circulating epidemic strain.

Nevertheless, as shown here, HAdV and HCMV frequently may cause active infection in preterm infants. Both viruses colonize the upper respiratory tract. In this way, both viruses can increase the risk of developing BPD in individual patients, especially in very immature infants. Both viruses induce early lung inflammation $(25,26)$ associated with increased expression of proinflammatory cytokines and chemokines $(27,28)$. One could speculate that both viruses may trigger inflamma- tory processes in the immature lung, supporting the development of chronic lung disease such as BPD. On the other hand, we and others could demonstrate that the proinflammatory cytokine TNF- $\alpha$ stimulates expression of HCMV immediate early proteins which are known to trigger inflammatory processes (for review see reference 29). Thus, active HCMV infection may not only promote development of BPD but, in turn, HCMV replication may be enhanced in the BPD lung by an inflammatory process. Although our data are suggestive, extended studies including more patients are needed to prove this relationship.

Acknowledgment. We would like to thank Karin Muske and Milli Heitmann for excellent technical assistance and Paul A. Stevens and Martin Raftery for help in preparing the manuscript.

\section{REFERENCES}

1. Horbar JD, Carpenter JH 1998 Vermont-Oxford Network 1997 Database Summary. Burlington, Vermont

2. Pierce MR, Bancalari E 1995 The role of inflammation in the pathogenesis of bronchopulmonary dysplasia. Pediatr Pulmonol 19:371-378

3. Numazaki K, Chiba S, Kogawa K, Mumetsu M, Motoya H, Nakao T 1993 Chronic respiratory disease in premature infants caused by Chlamydia trachomatis. J Clin Pathol 39:84-88

4. Iles R, Lyon A, Ross P, McIntosh N 1996 Infection with Ureaplasma urealyticum and Mycoplasma hominis and the development of chronic lung disease in preterm infants. Acta Paediatr 85:482-484

5. Wang EEL, Ohlsson A, Kellner JD 1995 Association of Ureaplasma urealyticum colonization with chronic lung disease of prematurity: results of a metaanalysis. J Pediatr 127:640-644

6. Sawyer MH, Edwards DK, Spector SA 1987 Cytomegalovirus infection and bronchopulmonary dysplasia in preterm infants. Am J Dis Child 141:303-305

7. Ballard RA, Drew WL, Hufnagle KG, Riedel PA 1979 Acquired cytomegalovirus in preterm infants. Am J Dis Child 133:482-485

8. Couroucli XI, Welty SE, Ramsay PL, Waerden ME, Fuentes-Garcia FJ, Ni J, Jacobs TN, Towbin JA, Bowles NE 2000 Detection of microorganisms in the tracheal aspirates of preterm infants by polymerase chain reaction: association of adenovirus infection with bronchopulmonary dysplasia. Pediatr Res 47:225-232

9. Van den Veyver IB, Ni J, Bowles N, Carpender RJ Jr, Weiner CP, Vankowitz J, Moise KJ Jr, Henderson J, Towbin JA 1998 Detection of intrauterine viral infection using the polymerase chain reaction. Mol Genet Metab 63:85-95

10. Alford CA, Stagno S, Pass RF, Britt WJ 1990 Congenital and perinatal cytomegalovirus infections. Rev Infect Dis 12:S745-753

11. Abzug MJ, Levin MJ 1991 Neonatal adenovirus infection: four patients and review of the literature. Pediatrics 87:890-896

12. Kim JS, Han HS, Park SH, Chung YK, Lee HJ, Chi JG 1997 Neonatal adenoviral pneumonia: report of three autopsy cases. J Korean Med Sci 12:146-150

13. Rieger-Fackeldey E, Aumeier S, Genzel-Boroviczeny O 2000 Disseminated adenovirus infection in two premature infants. Infection 28:237-239

14. Yeager AS, Palumbo PE, Malachowski N, Ariagno RL, Stevenson DK 1983 Sequelae of maternally derived cytomegalovirus infections in preterm infants. J Pediatr 102:918-922

15. Stagno S, Reynolds D, Pass R, Alford C 1980 Breast milk and the risk of cytomegalovirus infection. N Engl J Med 302:1073-1076

16. Vochem M, Hamprecht K, Jahn G, Speer CP 1998 Transmission of cytomegalovirus to preterm infants through breast milk. Pediatr Infect Dis J 17:53-58

17. Hamprecht K, Maschmann J, Vochem M, Dietz K, Speer CP, Jahn G 2001 Epidemiology of transmission of cytomegalovirus from mother to preterm infant by breastfeeding. Lancet 357:513-518

18. Poddar SK 1999 Detection of adenovirus using PCR and molecular beacon. J Virol Methods 82:19-26

19. Dahme M, Seidel W, Flunker G, Peters A, Wiersbitzky S, Reddemann H 1994 Detection of adenoviruses in blood by polymerase chain reaction. In: Rolfs A, Weber-Rolfs I, Finckh U (eds) Methods in DNA Amplification. Plenum Press, New York, pp 179-184

20. Prösch S, Kimel V, Dawydowa I, Krüger DH 1992 Monitoring of patients for cytomegalovirus after organ transplantation by centrifugation culture and PCR. J Med Virol 38:246-251

21. Döcke WD, Prösch S, Fietze E, Kimel V, Zuckermann H, Klug C, Syrbe U, Krüger DH, von Baehr R, Volk HD 1994 Cytomegalovirus reactivation and tumor necrosis factor. Lancet 343:268-269

22. Bauer H, Ting Y, Greer CE, Chambers JC, Tashino CJ, Chimera J, Reingold A, Manos MM 1991 Genital human papilloma virus infection in female university students as determined by a PCR-based method. JAMA 265:472-477 
23. Thompson JD, Higgins DG, Gibson TJ 1994 CLUSTAL W: improving the sensitivity of progressive multiple sequence alignment through sequence weighting, position specific gap penalties and weight matrix choice. Nucl Acids Res 22:4673-4680

24. Lukashok SA, Horwitz MS 1997 Adenovirus persistence. In: Ahmed R, Chen I (eds) Persistent Viral Infection. John Wiley and Sons, Chichester, United Kingdom, pp $147-160$

25. Grundy JE, Shanley JD, Griffith PD 1987 Is cytomegalovirus interstitial pneumonitis in transplant recipients an immunopathological conditions? Lancet ii:996-999

26. Ginsberg HS, Horswood RL, Chanock RM, Prince GA 1990 Role of early genes in the pathogenesis of adenovirus pneumonia. Proc Natl Acad Sci USA 87:6191-6195
27. Michelson S 1998 Mechanism of immunosuppression by human cytomegalovirus. In: Scholz M, Rabenau HF, Doerr HW, Cinatl J (eds) CMV-related immunopathology. Monographs in Virology, Vol 21. Karger, Basel, Switzerland, pp 12-28

28. Booth JL, Metcalf JP 1999 Type-specific induction of interleukin-8 by adenovirus. Am J Respir Cell Mol Biol 21:521-527

29. Prösch S, Volk HD, Reinke P, Pioch K, Döcke WD, Krüger DH 1998 Human cytomegalovirus infection in transplant recipients: role of TNF- $\alpha$ for reactivation and replication of human cytomegalovirus. In: Scholz M, Rabenau HF, Doerr HW, Cinatl $\mathrm{J}$ (eds) CMV-related immunopathology. Monographs in Virology, Vol 21. Karger, Basel, Switzerland, pp 29-41 